\title{
Factors for effectiveness in cultural landscape protection - the cultural park old town in Wrocław
}

\author{
Tomasz Ossowicz \\ tomasz.ossowicz@pwr.edu.pl \\ Wydziat Architektury, Politechnika Wrocławska
}

\begin{abstract}
After four years from funding of The Cultural park "Old Town" in Wrocław, before elaboration of required by law plan of protection for it, basing on large experience from time of its functioning, three factors of its effectiveness in cultural midtown landscape protection are examined: quality of construction of selected bans and limitations binding in the Park, ability of teams responsible for implementation, and kinds of procedures being applied in the park.
\end{abstract}

Key words: cultural park, cultural landscape protection, midtown, Old Town in Wrocław.

Numerous institutions of cultural parks on historic core of cities as an important instrument of cultural landscape protection is a relatively new practice in Poland. The first one was instituted in Cracow for Old Town with Wawel Castle (about 96 ha) in 2010 year, second one comprised a part of Radom (Stary Radom) in 2011. The third one is established in Wrocław for medieval Old Town, Ostrów Tumski, and islands on Odra river (210 ha) in 2014 year. Two parks covered areas along principal midtown streets: Piotrkowska in Łódź (2015), and Krupówki in Zakopane (2016). Next two were created in 2016 year on historical cores of Brzeg (Książęce Miasto Brzeg), and Bieruń (Obszar Staromiejski).

All these cultural parks distinguish from the rest $28^{1}$ ones by comparatively high figure of entities functioning in their spaces independently one another: institutions, companies, nongovernmental organisations, various businesses. Their areas are divided into numerous properties in hands of large number of private and public owners.

This paper has to deliberate factors for effectiveness in protection of midtown cultural landscape by creation of Cultural park "Old Town" in Wrocław. We consider three factors, which have a crucial importance: quality of legal bans and limitations within the park, abilities of a team, which has to manage the park, and kinds of procedure being applied in the Park.

But at first let us remind shortly, what does it mean "cultural park" according to Polish law on protection monuments and heritage in 2018 year.

\section{The essence of cultural park}

The cultural park is an instrument for protection cultural landscape as well as for preservation areas distinctive in landscape by presence of historical monuments (relics) characteristic for local building and settlement tradition. It is to be instituted by local municipal council in form of resolution. Operationally the cultural park is a combination of four interconnected tools. First one, introduced within resolution, is a set of legal bans and limitations on: building works, some economic activities including industry, shopping, and services, use of 
historical monuments, advertising in open space, street furniture, and waste management. Second tool has to be "a plan for protection" adopted by municipal council, which contents all planned actions and activities in order to preserve values of cultural landscape on the park area. Third tool is a local legally binding development plan (or plans), which must be elaborated and adopted for whole area of the park. It practically means, there is impossible to develop something before this plan is adopted. Municipality may facultatively institute special organizational unit to manage instituted cultural park and this is the last tool.

\section{Cultural park in Wrocław}

In Wrocław cultural park was established as an instrument to realize mainly clearly defined goal. After almost two decades long process of revitalization, the oldest parts of the city changed very positively their appearance in its architectural and spatial dimensions. Majority of buildings are renovated, empty areas, where row tenement houses were destroyed as a result of the World War II, are filled with new smart contemporary buildings, almost all pavements are replaced by new ones, some street are pedestrianized. Majority of area was covered by legally binding local development plans, which were effective instruments of architectural and spatial harmonization. Public spaces are very alive and full of people, main squares and streets are city stages for many attractive events. But the elegant and nice old fashioned spaces were utilized by businesses, institutions, and sometimes inhabitants in a way neither elegant nor nice. Layers of outdoor advertisement cover wall, roofs, windows, monumental facades, balustrades, poles, and even pavements. Various devices (air conditioning or antennas) installed on outside cover of buildings blemished them. Many walls or fencings were damaged, covered with graffiti, or never replaced old posters. One could see ugly shopping stands and food tracks making dissonance with historical surroundings. Therefore, the main goal was to purge radically outdoor space of all these things and to give opportunity for good exposition of beauty of townscape as well as to provide comfort for people in a midtown space.

In terms of effective implementation of the instrument it was primarily urgent to introduce set of legal regulations in order to restrict all escalating negative phenomena. The act with regulations was adopted in 2014 with one year vacatio legis to give time all users and owners to adapt their activities to new restrictions. It was also assumed, that after three years of monitoring of results municipality would begin process of elaboration of a plan for protection which indicates supplementary actions. In 2016 taking into account some practical experience the regulations were modified by municipal council. Nowadays a protection plan is in a course of elaboration. On this account it is very good time for consideration on effectiveness of current functioning of the Park.

Now we consider three factors, which have a crucial impact on effectiveness of protection of town cultural landscape.

\section{Quality of legal regulation}

Solutions of certain selected problems are examined here.

\section{Advertising activity in space}

With respect to historical character as well as architectural richness of many facades in general advertising activity on building walls and roofs in the Park is forbidden. However it is impossible to ban signboards, which are also advertisement, but they are necessary to give information about shops, restaurants and others businesses, or institutions. But what way to distinguish expressly signboards from other forms of advertisements, especially from these aggressive ones? It is required a very precise definition clear either for business owner or for member of City Guard, who has control respecting of regulations in the Park. According to Wrocław definition signboard is a material thing used to present graphical or textual signifying of given subject containing no more than: firm or name, logo, kind of activity, address, phone number, opening hours, and mail address or website. Thus equivalence of terms and regulations is fundamental. 
Next matter is how to limit size of signboards. One of solutions is to define maximal dimensions of individual signboards. But facing a great diversity of facades in the Park, it is almost impossible to construct universal system of limitations. Yet the goal is to protect facades from visual domination of signboards. Thus in the Wrocław Park it is a limit for share of a facade area, which can be covered by all signboards. As an effect of a series of experimental drawings this percentage is accepted on a level of 4 percent. The operational question is, who is responsible to respect this limit. No individual owner of shop, restaurant or other business, because an outside facade is common. Thus this is a role of an administrator of the house and experience from Wrockaw answers that this solution does work. Of course in addition in the Park it is forbidden to cover with signboards important element of façade composition like: windows, balustrades, sculptures, paintings, sgraffitos, corniches, stripes around windows and doors.

\section{Protective covers on scaffolds}

During renovation of building elevation usually a scaffold is temporary constructed. It has to be covered from outside with a kind of strong textile as well for safety of workers as to protect surroundings from dust. It became highly profitable to put an advertisement on this textile in size of a whole facade. The profit from this practice is going not only to contractor but frequently to an owner or inhabitants, and thus it becomes a source of money for renovation. Moreover in front of some houses scaffold was kept much longer time (several years) after real completion of renovation. In some cases scaffold was anchored to facade forever.

The solution used in the Park consists of three regulations. An advertisement on a cover of scaffold is allowed only for one year, because it is average time needed for renovation of facade. Next time it is permitted after ten years. In addition advertisement may take no more than $1 / 3$ of area of a cover while the rest must be a mapping of facade being renovated.

\section{Windows as windows}

One of the important objectives to achieve in the Park is "to keep windows as serving like windows". Consequently glass in windows should be transparent. It was also important to come back as much as possible to XIXth century arrangement of shop or business windows especially on ground level with presentation of merchandize with very refined decoration. Before institution of the Park majority of glass in business windows was covered with not transparent self-adhesive advertisements, especially in banks and shops.

In the Park long series of regulations serves to realize assumed objectives. Advertisements behind windows are allowed only as menu of restaurants or cafes, programs of operas, theatres, concert halls, cinemas, and, what is important, if they are elements of decorative arrangement with merchandize. All glass has to be transparent, however there are some practical exceptions: stained glass, artistic composition (no more than 25 per cent of each glass area), during artistic exhibitions (temporary), as a coverage of cash machines, and during renovation. In the last four cases only grey sand color is accepted. Also information about: form of payment, opening hours, tax VAT refund, security firm, and sale or rent can be located just on glass. Part of these regulation were introduced within the change in 2016 year, after many experiences as well as discussions with business owners.

\section{Clean facades}

From 2016 year the ban of keeping facades uglified, covered with graffiti, damaged, or plastered with posters. This way responsibility for protection elevations from graffiti writers or persons who illegally plaster posters lies on administrators of houses. As an effect municipality found large number of partners in fighting against illegal graffiti. In legal aspect it is important to form this kind of regulation in form of a ban but not as a mandatory prescript. Nota bene the best way to prevent illegal graffiti and posters is to cover a wall with a mural. Perhaps illegal writers feel themselves as artists and they have a respect to other artist works. 


\section{Abilities of the team}

It could be considered some models of management in midtown cultural parks. First one is to create separate unit using possibility given by law. Second consists in location the competence in one of departments of municipality. In Wrocław third option is applied as an example of horizontal approach in municipal management. Special interdisciplinary Working Team (Zespół Roboczy) is organized for everyday work in the Park, and second one larger Advisory Group (Grupa Doradcza) for strategic decisions. The crucial factor is a presence of representatives from departments, which are strongly involved in matters connected with protection of cultural landscape on area of the Park.

At first it is needed someone specialized in historical monument preservation. In Wrocław it is a worker from The Office of Municipal Conservator of Historical Monuments. He or she is needed not only by professional knowledge, but also in order to coordinate standard Conservator procedures with ones being realized by the team. We have to remember that Conservator substantively is a chain of state system of monument preservation with the Ministry of Culture and National Heritage on its top, while the Team acts on behalf of City Mayor independently from central government institutions.

At second, it is very important, perhaps crucial is to have a representative of City Guard in the Team. Its members every day control area of the park and they are in contact with businesses and persons who violate regulations. Members of City Guard need strongly permanent contact with other specialists participating in the team to have immediate explanation on sense of regulations and objectives to realize on the Park area. They are also able to charge (sometimes repeatedly) with penalties on these, who refuse to liquidate violations.

Next, representative of the department responsible for general aesthetic appearance of the city space, especially for: street furniture, art in public spaces as well as murals, should become a member of the Working Team. There is a special position of "Coordinator aesthetic arrangement of the city" within Wrocław municipal Department of Architecture and Building. Her or his co-worker is a permanent participant of the cultural park Team. We have to see that many of buildings and constructions on the park are not historical monuments.

Also someone from department of economic development is needed, because it is usually responsible for support to street businesses and is being in permanent contact with them, it knows their problems and needs. Usually this department negotiates conditions of events in public space like fairs or kermises with companies being their organizers.

Very useful is unceasing presence of a lawyer, and sometimes a legal counsel. The Team should collaborate with delegated workers from other municipal units specially: department of urban planning, because it is responsible for general spatial strategy and a general vision of the city as well as elaborates local development plans, road authority, which manages streets an squares within the Park, department of culture, as an organizer of cultural events in public spaces, department of greenery, management of municipal housing, because is responsible for housing yards.

In Wrocław first four mentioned departments are permanent represented in Working Team, but all participates in Advisory Group. The Chairman of this second body is one of Deputy Mayors of the City, while Deputy Chairman responsible for the plan for protection is an urban planner.

\section{Procedures}

Municipality may implement one of two strategies in a sphere of procedures used in cultural park. First one is to be radical according to motto: "Zero tolerance for violations". Opposite principle is to collaborate with everyone, who is open for it, due to philosophy: "Let us do it together". In Wrocław second approach was chosen. It was assumed that partnership and consequence would be more effective than the severity and rigorousness. Then in each situation at first soft procedures are performed, and only if lack of other way hard ones are applied. The steps from soft to hard ones are as follows:

- Vacatio legis of regulations. After adoption of bans and limitations in 2014 municipality gave one year to businesses and inhabitants to adjust to them. Experience showed that so long time is not necessary and vacatio legis for changes in regulations adopted in 2016 was only 6 months. 
Public institutions has to respect regulations as first ones. Several public and even municipal institutions are not satisfied from regulations in the Park and they demanded more freedom. But if they would be exempted from some regulations as an exception, private bodies will not accept nor bans neither limitations. The equality before the law is a crucial matter to have a success.

- Notice with negotiated date. In case of documented violation first step is to send notice with claim to remove it before defined date. Better to be open for proposal of prolongation of time. Wrocław experience shows that time of prolongation proposed by a company or a person were respected more than date imposed by municipality.

- Collaboration to find good solution. If given company or person has a problem to fulfill requirements, municipality should collaborate with them to find satisfactory solution as well for user as with respect to bans and limitations. For example according to regulations in the Wrocław Park installation of air condition devices on buildings visible from streets or squares is forbidden. However many restaurants and cafés cannot function without them and only one place to locate them is an outside wall. Municipality supports this kind of activity in the Park and therefore staff of municipal conservator of monuments collaborate with designers hired by restaurant owners to find way of camouflage necessary devices in decorative elements of façades frequently with very good results. This kind of workshops are sometimes practiced by staff of Coordinator of Aesthetic Arrangement of the city on creation of signboards.

- Promotion of good practices. Good examples are collected. In future a competition for the best shopping window, and the best facade is planned.

- Penalties as an extreme solution. In extremal situation, when listed above procedures are ineffective The City Guard has a right to charge company, person, or institution with financial penalty, and it can be repeated as soon as violation will be removed. However in majority of situations this instrument was not necessary to achieve positive results in Wrocław, a possibility of its application may be considered as a key to a success of midtown city cultural park. Before the park was instituted, two kind of procedures were used to remove violations: conservatorial and building ones. To put it simply, they consist in sending a notice with claim to remove violation. After lack of reaction conservator or building contoller sends complaint to an administrative court. This procedure although long, may be effective if the matter is a building or its part illegally constructed. However, if for example any large size advertisement was hang up without conservator permission, this procedure is ineffective. Just before date of a court case owner of advertisement removes it of his own volition and a court with satisfaction discontinues the proceedings. Everyone is happy, but some days after different advertisement is hang up anew. All procedure seems a shooting at a fly with a heavy cannon. If our cannon is precisely leveled at a fly, it suddenly blow off. Immediate charging ones who violates cultural park bans or limitations with financial penalties in extreme cases is much more effective, than other possible procedures legal in Poland.

More than four years of practice in Wrocław shows need for coordination of procedures realized by the Park working team with proceedings by various units of municipality included: conservator of monuments, coordinator of aesthetic arrangement of the city, road authority, construction supervisor.

In general implementation of regulations in Cultural park "Old Town" in Wrocław is very effective. For example only in time of first 14 months after vacatio legis 658 violations were removed, included: 26 whole façade size advertisements, 23 billboards, 171 banners, 67 citylights, 196 self-adhesive advertisements on windows. Barely in first nine months of 201819 walls covered with graffiti were renovated.

The matter of effectiveness is crucial for success of midtown cultural parks in Poland. In this paper merely three factors of it were examined only for the Wrocław park: quality of legal regulations, ability of implementation team, and kind of procedures. Facing a wide spread of this instrument in the country further it becomes clear that further analyses of other parks and of other factors is very needful. 


\section{References}

[1] Ossowicz T., 2014. Midtown cultural park (in Polish). Zeszyt 01/2014. Stowarzyszenie Urbanistów ZOIU. Wrocław. 5-12.

[2] Ossowicz T., 2015. What way to determine principles and conditons for locations of advertisement boards and installations in a cultural park? The Cultural Park "Old Town" in Wrocław (in Polish). Zeszyt 02/2015. Stowarzyszenie Urbanistów ZOIU. Wrocław. 13-18.

[3] Trzewik J., 2014. Cultural park as a form of limitation of economic activity (in Polish) in: Economic activity on areas under protection (in Polish), Biskup R., Pyter M., Trzewik J. (ed.), KUL, Lublin.

[4] Resolution nr LVI/1465/14 of Municipal Council of Wrocław $10^{\text {th }}$ April 2014 year on institution of cultural park "Old town" and

[5] Resolution nr XXXII/686/16 of Municipal Council of Wrocław 24 $4^{\text {th }}$ November 2016 year on amendment of Resolution nr LVI/1465/14 of Municipal Council of Wrocław 10th April 2014 year on institution of cultural park "Old town".

\section{Czynniki skuteczności w ochronie krajobrazu kulturowego - park kulturowy „Stare Miasto” we Wrocławiu}

Streszczenie: Po czterech latach od utworzenia Parku kulturowego "Stare Miasto" we Wrocławiu, a przed opracowaniem wymaganego prawem planu ochrony dla niego, na podstawie bogatych doświadczeń z okresu jego działania, poddane są analizie trzy czynniki jego skuteczności w zakresie ochrony śródmiejskiego krajobrazu kulturowego: jakość konstrukcji obowiązujących w Parku zakazów i ograniczeń, kompetencji zespołu wdrażającego te regulacje oraz rodzaje stosowanych w nim procedur.

Słowa kluczowe: park kulturowy, ochrona krajobrazu kulturowego, śródmieście, Stare Miasto we Wrocławiu 